\title{
Prevalence of Hepatitis C Virus Infection and Its Risk Factors among Patients Attending Rwanda Military Hospital, Rwanda
}

\author{
Esperance Umumararungu, ${ }^{1,2}$ Fabien Ntaganda, ${ }^{2}$ John Kagira, ${ }^{1,3}$ and Naomi Maina ${ }^{1,4}$ \\ ${ }^{1}$ Department of Molecular Biology and Biotechnology, Institute of Basic Sciences, Technology and Innovation (PAUISTI), \\ Pan African University, P.O. Box 6200-00200, Nairobi, Kenya \\ ${ }^{2}$ Rwanda Military Hospital, P.O. Box 3377, Kanombe, Kigali, Rwanda \\ ${ }^{3}$ Department of Animal Sciences, Faculty of Agriculture, Jomo Kenyatta University of Agriculture and Technology (JKUAT), \\ Nairobi, Kenya \\ ${ }^{4}$ Department of Biochemistry, School of Biomedical Sciences, Jomo Kenyatta University of Agriculture and Technology (JKUAT), \\ P.O. Box 62000-00200, Nairobi, Kenya
}

Correspondence should be addressed to Naomi Maina; nmaina@jkuat.ac.ke

Received 24 October 2016; Revised 7 December 2016; Accepted 18 December 2016; Published 26 January 2017

Academic Editor: Mohamed T. Shata

Copyright (C) 2017 Esperance Umumararungu et al. This is an open access article distributed under the Creative Commons Attribution License, which permits unrestricted use, distribution, and reproduction in any medium, provided the original work is properly cited.

\begin{abstract}
In Rwanda, the prevalence of viral hepatitis (HCV) is poorly understood. The current study investigated the prevalence and risk factors of HCV infection in Rwanda. A total of 324 patients attending Rwanda Military Hospital were randomly selected and a questionnaire was administered to determine the risk factors. Blood was collected and screened for anti-HCV antibodies and seropositive samples were subjected to polymerase chain reaction method. Hematology abnormalities in the HCV infected patients were also investigated. Anti-HCV antibody and active HCV infection were found in $16.0 \%$ and $9.6 \%$ of total participants, respectively. Prevalence was highest $(28.4 \%$; $19 / 67)$ among participants above 55 years and least $(2.4 \% ; 3 / 123)$ among younger participants $(18-35$ years). There was a significant $(P=0.031)$ relationship between place of residence and HCV infection with residents of Southern Province having significantly higher prevalence. The hematological abnormalities observed in the HCV infected patients included leukopenia $(48.4 \% ; 15 / 52)$, neutropenia $(6.5 \% ; 2 / 52)$, and thrombocytopenia $(25.8 \%$; $8 / 52)$. The HCV infection was significantly higher in the older population ( $>55$ years) and exposure to injection from traditional practitioners was identified as a significant $(P=0.036)$ risk factor of infection. Further studies to determine the factors causing the high prevalence of HCV in Rwanda are recommended.
\end{abstract}

\section{Introduction}

Globally, about 130-150 million people are living with chronic HCV infection [1] with about 350,000-500,000 lives lost every year $[2,3]$. Infection begins as acute and usually asymptomatic during early stages $[4,5]$. In most untreated cases, the infection progresses into chronic infections and gradually develops liver fibrosis which then leads to cirrhosis, liver damage, and hepatocellular carcinoma (HCC) [6]. In Africa, the prevalence of HCV is between $0.1 \%$ and $17.5 \%$. In Rwanda, prevalence of HCV infection has been reported in specific groups of the populations such as in pregnant women and in patients infected with tuberculosis and HIV [7-10].
However, the prevalence of $\mathrm{HCV}$ for the general population is not clear. A prevalence of $4.9 \%$ was estimated in a 2011 study [11] but a recent review by Karoney and Siiki indicates that this figure could be an underestimation [12]. This is because of challenges such as barriers to screening, cost-related factors, and inadequate knowledge and awareness of hepatitis $\mathrm{C}$ [13].

There are many risk factors of acquiring HCV infection. In the Sub-Saharan Africa, practices such as dental surgery, therapeutic injection, intravenous drug, and age have been reported as major risk factors associated with $\mathrm{HCV}$ infection [14-16]. In Rwanda, the exact risk factors of HCV infection are not clear. 
The aims of the current study were to determine the prevalence, hematological abnormalities, and risk factors associated with HCV infection in patients attending Rwanda Military Hospital (RMH), a national referral hospital in Rwanda.

\section{Materials and Method}

2.1. Study Site, Study Design, and Population. The study was conducted at the Rwanda Military Hospital (RMH), a national referral and teaching hospital with a bed capacity of 500 located at Kanombe, in Kicukiro District of Kigali Province, Rwanda. The hospital provides health care services to around 40,000 to 50,000 patients including military personnel every year. The study utilized out-patients referred for laboratory examination and who were 18 years and above. Using Kish Leslie formula [17] for cross-sectional studies and an average prevalence of $3.5 \%$ from two previous studies $[7,10]$, a sample size of 324 was determined. The sample size was spread across a two-month period and subsequently divided into 9 patients per day per month. Therefore, 9 patients/day attending laboratory were randomly enrolled after they had given informed consent. Information about the study was given in English, French, or Kinyarwanda. A structured questionnaire to obtain bio-data and exposure risks such as blood transfusion, organ transplantation, living with $\mathrm{HCV}$ infected patients, hospital admission, previous surgery, and hospitalization; accidental needle stick injuries treated by traditional doctor and travelling outside were also administered.

2.2. Blood Collection, Processing, and HCV Antibody Screening. About $10 \mathrm{~mL}$ of venous blood from the median cubital vein was collected into ethylenediaminetetraacetic acid (EDTA) tubes. Five milliliters of this blood was centrifuged for $10 \mathrm{~min}$ at $3000 \mathrm{RPM}$ to obtain plasma. An aliquot of $500 \mu \mathrm{L}$ of each plasma sample was made and screened for anti-HCV antibody using Cypress anti-HCV dipstick following instructions of the manufacturer's manual [18]. The sensitivity and specificity of the assay used are $95.29 \%$ and $98.75 \%$, respectively. The remaining plasma samples of all anti-HCV antibody positive samples were aliquoted in two cryovials and stored at $-80^{\circ} \mathrm{C}$ for $\mathrm{HCV}$ RNA testing.

2.3. Hematological Analysis. EDTA blood samples of seropositive participants ( $5 \mathrm{~mL}$ each) were subjected to hematology analysis using Sysmex XS800i Automatic Analyzer [19]. Full blood count including white blood cell differential counts was determined. The erythrocyte sedimentation rate (ESR) was also measured using Westergren method [20].

2.4. HCV RNA Testing. Active RNA infection of all seropositive samples was confirmed by HCV RNA testing. One vial of cryopreserved plasma was retrieved from $-80^{\circ} \mathrm{C}$ freezer and thawed at room temperature for $15 \mathrm{~min}$. Following manufacturer's manual, HCV RNA was automatically extracted from $650 \mu \mathrm{L}$ plasma samples, reverse transcribed into complementary DNA (cDNA), and amplified and amplicons

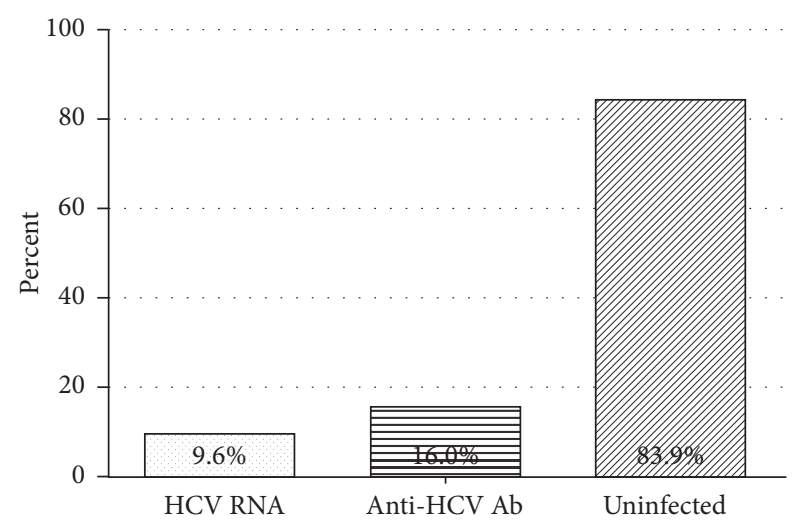

FIGURE 1: Prevalence of HCV Infection among patients attending laboratory at RMH.

were detected using Cobas AmpliPrep/Cobas TaqMan HCV machine, version 2 [21]. Detection of viremia was recorded as target detected or target not detected.

2.5. Statistical Analysis. All data were entered and analyzed in Statistical Package for the Social Sciences (SPSS) software version 20.0 for windows [22]. Comparison between categorical variables was computed using Fisher's exact test or Pearson Chi-square test. A $p$ value of less than 0.05 was considered statistically significant.

2.6. Ethical Statement. This study was approved by the Institutional Ethical Review Committee (IRC) of the Rwanda Military Hospital.

\section{Results}

Of the 324 study participants, 133 (41.0\%) were males and $191(59.0 \%)$ were females. The mean age of the participants was 42.32 years. The demographic characteristics of the study participants are shown in Table 1 . Serological testing for HCV of all 324 participants revealed that 16.0\% (52/324) of them were seropositive. Confirmation of active $\mathrm{HCV}$ RNA infection among seropositive participants revealed that, of the 52 anti-HCV positive participants, 31 (59.6\%) had detectable viremia. Thus, an overall active $\mathrm{HCV}$ prevalence of $9.6 \%$ (31/52) was recorded (Figure 1).

Prevalence of active HCV infection was higher (9.8\%, $3 / 31)$ in males than in females $(9.4 \%, 18 / 31)$. However, this was not significant $\left(p=0.916, \chi^{2}=0.011\right)$ (Table 2 ).

The participants were divided into three age categories. Anti-HCV antibodies were detected in $41.8 \%$ of participants older than 55 years, $11.9 \%$ middle age participants (3655 years), and $6.5 \%$ younger participants (18-35 years). In general, it was observed that prevalence of active $\mathrm{HCV}$ infection increased significantly with increasing age $(p=$ 0.001) (Table 3).

Prevalence of active HCV infection was highest among participants born in Southern Rwanda $(13.1 \%, 13 / 86)$ and least among participants born outside Rwanda (3.9\%, 3/74). However no significant relationship was found between 
TABLE 1: Demographic characteristics of participants in the study.

\begin{tabular}{|c|c|}
\hline Variable & Number of Participants (\%) \\
\hline \multicolumn{2}{|l|}{ Gender } \\
\hline Male & $133(41.0 \%)$ \\
\hline Female & $191(59.0 \%)$ \\
\hline \multicolumn{2}{|l|}{ Age group (yrs) } \\
\hline $18-35$ & $123(38.0 \%)$ \\
\hline $36-55$ & $143(41.4 \%)$ \\
\hline$>55$ & $67(20.7 \%)$ \\
\hline \multicolumn{2}{|l|}{ Marital Status } \\
\hline Single & $73(22.5 \%)$ \\
\hline Married & $207(63.9 \%)$ \\
\hline Divorced & $37(11.4 \%)$ \\
\hline Widow & $7(2.2 \%)$ \\
\hline \multicolumn{2}{|l|}{ Employment sector } \\
\hline Commerce & $71(21.9 \%)$ \\
\hline Health & $13(4.0 \%)$ \\
\hline Agriculture (farming) & $46(14.2 \%)$ \\
\hline Security & $35(10.8 \%)$ \\
\hline Transport & $8(2.5 \%)$ \\
\hline Education and religion & $44(13.6 \%)$ \\
\hline Technical staff & $15(4.6 \%)$ \\
\hline Unemployed & $73(22.5 \%)$ \\
\hline Other & $19(5.9 \%)$ \\
\hline \multicolumn{2}{|l|}{ Place of birth } \\
\hline Kigali & $47(14.5 \%)$ \\
\hline Southern & $103(31.8 \%)$ \\
\hline Northern & $33(10.2 \%)$ \\
\hline Eastern & $39(12.0 \%)$ \\
\hline Western & $24(7.4 \%)$ \\
\hline Abroad & $78(24.1 \%)$ \\
\hline \multicolumn{2}{|l|}{ Place of Residence } \\
\hline Kigali & $241(74.4 \%)$ \\
\hline Southern & $27(8.3 \%)$ \\
\hline Northern & $22(6.8 \%)$ \\
\hline Eastern & $27(8.3 \%)$ \\
\hline Western & $7(2.2 \%)$ \\
\hline \multicolumn{2}{|l|}{ Level of Education } \\
\hline Primary & $118(36.4 \%)$ \\
\hline Secondary & 119 (36.7\%) \\
\hline Tertiary & $73(22.5 \%)$ \\
\hline None & $14(4.3 \%)$ \\
\hline
\end{tabular}

TABLE 2: Gender wise distribution of anti-HCV antibodies and HCV RNA.

\begin{tabular}{lccc}
\hline Gender Number of participants & Anti-HCV +ve & HCV RNA +ve \\
\hline Male & 133 & $24(18.0 \%)$ & $13(9.8 \%)$ \\
Female & 191 & $28(14.7 \%)$ & $18(9.4 \%)$ \\
\hline Total & 324 & $52(16.0 \%)$ & $31(9.6 \%)$ \\
\hline
\end{tabular}

participant's birth place and active HCV RNA infection ( $p=$ $\left.0.390, \chi^{2}=5.213\right)$. In contrast, there was a significant $(p=$
TABle 3: Age wise Prevalence of anti-HCV antibodies and HCV RNA among study participants.

\begin{tabular}{lccc}
\hline Age group (yrs) Number of participants & Anti-HCV +ve HCV RNA \\
\hline $18-35$ & 123 & $8(6.5 \%)$ & $3(2.4 \%)$ \\
$36-55$ & 134 & $16(11.9 \%)$ & $9(6.7 \%)$ \\
$>55$ & 67 & $28(41.8 \%)$ & $19(28.4 \%)$ \\
\hline Total & 324 & $52(16.0 \%)$ & $31(9.6 \%)$ \\
\hline
\end{tabular}

TABLE 4: Distribution active HCV RNA infection according to marital status.

\begin{tabular}{lcc}
\hline Marital Status & Number of Participants & HCV RNA \\
\hline Single & 73 & $6(8.2 \%)$ \\
Married & 207 & $18(8.7 \%)$ \\
Divorced & 7 & $0(0.0 \%)$ \\
Widow/widower & 37 & $7(18.9 \%)$ \\
\hline Total & 324 & $31(9.6 \%)$ \\
\hline
\end{tabular}

$\left.0.031 ; \chi^{2}=10.627\right)$ relationship between participants place of residence and active RNA infection. Infection was highest among residents of Southern followed by Western, Eastern, Northern, and Kigali (Figure 2).

$\mathrm{HCV}$ infection was most commonly found among widows/widowers and none of divorced participants was positive as shown in Table 4. However, no significant relationship was found $(p>0.05)$

Comparison of risk factors of acquiring HCV infection among participants was also analyzed (Table 5). It was observed that participants who had received injection from traditional practitioners had a significant $(p=0.036)$ chance of having HCV infection. Similarly, persons who had lost a relative through hepatitis $\mathrm{C}(\mathrm{HC})$ and those with no educational background were more likely to have $\mathrm{HCV}$ infection.

Hematological abnormalities observed among the HCV infected participants were leukocytopenia (48.4\%), lymphopenia (3.2\%), neutropenia (6.5\%), and thrombocytopenia (25.8\%) (Table 6). The prevalence of neutrophil abnormalities (neutropenia) was significantly $(p=0.033)$ higher in males than in females. Leukocytopenia was more prevalent but not significant $(p>0.05)$ in males $(53.8 \%)$ than in females $(44.4 \%)$. In contrast, thrombocytopenia was more common in females (33.3\%) than males (15.4\%). Only one female $(5.6 \%)$ had anemia. Erythrocytes Sedimentation Rate (ESR) was recorded under two categories; $>20 \mathrm{~mm} / \mathrm{hr}$ and $<20 \mathrm{~mm} / \mathrm{hr}$. Overall 5 (16.1\%) HCV patients had ESR values above $20 \mathrm{~mm} / \mathrm{hr}$, with $23.1 \%$ and $11.1 \%$ being males and females, respectively.

\section{Discussion}

Viral hepatitis is a major infectious disease of global concern [23]. In Sub-Saharan Africa, viral hepatitis due to $\mathrm{HCV}$ infection is highly prevalent but the extent of the disease burden may be underreported [12, 24].

Prevalence of $\mathrm{HCV}$ infection varies across different regions and populations [25]. In Africa, prevalence of $\mathrm{HCV}$ 
TABLE 5: Risk/exposure factors of HCV infection among 324 study participants.

\begin{tabular}{|c|c|c|c|}
\hline Risk factor & $N$ & HCV RNA +ve & $p$ value \\
\hline \multicolumn{4}{|c|}{ Blood transfusion } \\
\hline Yes & 19 & $2(10.5 \%)$ & \multirow[t]{2}{*}{0.939} \\
\hline No & 304 & $29(9.5 \%)$ & \\
\hline \multicolumn{4}{|c|}{ Relative died of $\mathrm{HC}$} \\
\hline Yes & 57 & $8(14.0 \%)$ & \multirow{3}{*}{0.052} \\
\hline No & 261 & $21(8.0 \%)$ & \\
\hline Unknown & 6 & $2(33.3 \%)$ & \\
\hline \multicolumn{4}{|c|}{ Living with infected person } \\
\hline Yes & 51 & $7(13.7 \%)$ & \multirow[t]{2}{*}{0.271} \\
\hline No & 273 & $24(8.8 \%)$ & \\
\hline \multicolumn{4}{|l|}{ Hospitalized } \\
\hline Yes & 151 & $12(7.9 \%)$ & \multirow[t]{2}{*}{0.354} \\
\hline No & 173 & $19(11.0 \%)$ & \\
\hline \multicolumn{4}{|c|}{ Surgeries performed } \\
\hline Yes & 71 & $6(8.5 \%)$ & \multirow[t]{2}{*}{0.717} \\
\hline No & 253 & $25(9.9 \%)$ & \\
\hline \multicolumn{4}{|c|}{ Needle Injection by traditional practitioners } \\
\hline Yes & 19 & $5(26.3 \%)$ & \multirow[t]{2}{*}{$0.036^{*}$} \\
\hline No & 304 & $26(8.3 \%)$ & \\
\hline \multicolumn{4}{|c|}{ Treated by traditional doctor } \\
\hline Yes & 93 & $12(12.9 \%)$ & \multirow[t]{2}{*}{0.195} \\
\hline No & 231 & $19(8.2 \%)$ & \\
\hline \multicolumn{4}{|c|}{ Travelled outside before } \\
\hline Yes & 195 & $22(11.3 \%)$ & \multirow[t]{2}{*}{0.197} \\
\hline No & 129 & $9(7.0 \%)$ & \\
\hline \multicolumn{4}{|c|}{ Education background } \\
\hline Primary & 118 & $15(12.7 \%)$ & \multirow{4}{*}{0.097} \\
\hline Secondary & 119 & $10(8.4 \%)$ & \\
\hline Tertiary & 73 & $3(4.1 \%)$ & \\
\hline None & 14 & $3(21.4 \%)$ & \\
\hline
\end{tabular}

${ }^{*}$ Significant at $95 \%$ confidence interval.

TABLE 6: Prevalence of haematological abnormalities among HCV infected participants.

\begin{tabular}{|c|c|c|c|c|c|c|c|c|}
\hline \multirow{2}{*}{ Abnormality } & \multirow{2}{*}{$N(\%)$} & \multicolumn{2}{|c|}{ Gender } & \multirow{2}{*}{$p$-value } & \multicolumn{3}{|c|}{ Age (yrs) } & \multirow{2}{*}{$p$ value } \\
\hline & & Male & Female & & $18-35$ & $36-55$ & $>55$ & \\
\hline Leukopenia & $15(48.4 \%)$ & $7(53.8 \%)$ & $8(44.4 \%)$ & 0.605 & $3(75 \%)$ & $2(25 \%)$ & $10(52.6 \%)$ & 0.221 \\
\hline Lymphopenia & $1(3.2 \%)$ & $1(7.7 \%)$ & $0(\%)$ & 0.403 & 0 & 0 & $1(5.3 \%)$ & 0.853 \\
\hline Neutropaenia & $2(6.5 \%)$ & $1(7.7 \%)$ & $1(5.6 \%)$ & 0.332 & $1(25 \%)$ & 0 & $1(5.3 \%)$ & 0.296 \\
\hline Thrombocytopenia & $8(25.8 \%)$ & $2(15.4 \%)$ & $6(33.3 \%)$ & 0.260 & 0 & 0 & $8(42.1 \%)$ & $0.033^{*}$ \\
\hline Anaemia & $1(3.2 \%)$ & $0(0 \%)$ & $1(5.6 \%)$ & 0.388 & 0 & 0 & $1(5.3 \%)$ & 0.722 \\
\hline ESR & $5(16.1 \%)$ & $3(23.1 \%)$ & $2(11.1 \%)$ & 0.537 & 0 & $2(25 \%)$ & $3(15.8 \%)$ & 0.539 \\
\hline
\end{tabular}

${ }^{*}$ Significant at $95 \%$ confidence interval. Computed using Chi-square test. Reference range of hematological variables: total WBC count $\left(4.50-11.50\left[10^{3} / \mu \mathrm{L}\right]\right)$ lymphocytes (Female: $1.30-3.70$, males: $1.20-4.80\left[10^{3} / \mu \mathrm{L}\right]$ ); neutrophils (Females: $1.10-4.40$, males: $2.30-8.10\left[10^{3} / \mu \mathrm{L}\right]$ ); platelets $\left(150-540\left[10^{3} / \mu \mathrm{L}\right]\right.$ ), haemoglobin (Females: 11.0-17.0, Males: 12.0-18.0 [g/dL]), and ESR $(<20 \mathrm{~mm} / \mathrm{hr})$.

infection reported so far has focused on a specific group of the population mostly relying on the error-prone antibody testing method $[9,10,26,27]$. In this study, participants were first screened against the presence of HCV antibodies using rapid diagnostic strips. Seropositive cases were then subjected to the more sensitive polymerase chain reaction method. A high seroprevalence of $16.0 \%$ was reported in patients attending the national referral hospital in Rwanda. This figure is comparatively higher than the $1.3 \%$ seroprevalence reported by Kateera et al. with the same Cypress anti-HCV dipstick 


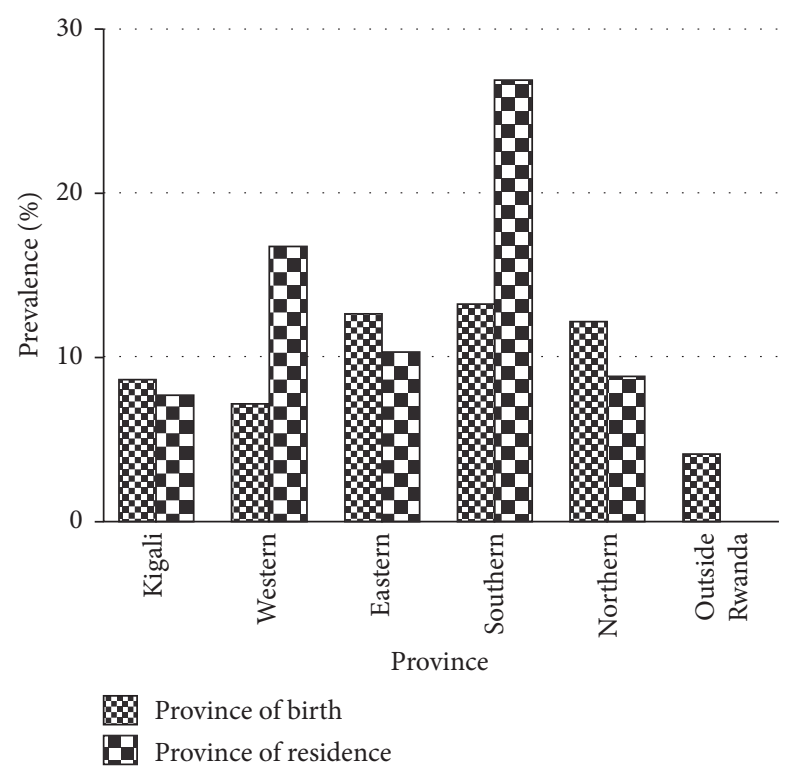

Figure 2: Prevalence of HCV RNA infection according to birth place and residence.

[7]. This test has $98.7 \%$ relative specificity for antibodies against both structural and nonstructural proteins of HCV [15]. However, the assay generally lacks the discriminatory ability to differentiate between antibodies resulting from active infection and previously cleared infection [28]. It is recommended that all patients having anti-HCV antibodies are subjected to further confirmatory testing thereby eliminating such false positives [29]. In this study, the overall prevalence of active HCV infection was $9.6 \%$ (31/324). This prevalence indicates the cost-effectiveness of screening using serological tests and confirmation by RNA. The current cost of RNA testing in Rwanda is about \$100.00, limiting the general public to only HCV antibody screening.

This study noted infection was higher in males than in females. Many studies have reported similar findings [30]. This high infection rate in males than in females may be due to spontaneous clearance of acute infection in females [31]. The reason to this clearance has been attributed occurrence of certain genetic factors such as IL28B genetic variants in females $[5,32]$. Indeed even the hematological abnormalities noted in this study were more in males than females; however there is a significant association of $\mathrm{HCV}$ infection and thrombocytopenia; this association has been reported earlier [33]. Similarly, prevalence of active HCV infection increased significantly with age and this has been reported in Uganda [34] and in Madagascar [16] and this may be due to frequent exposure [35]. With the high prevalence being reported in patients older than 55 years, more screening for $\mathrm{HCV}$ can focus on this age group.

In developing countries various risk factors associated with acquiring $\mathrm{HCV}$ infection have been reported in various studies. Identification of risk factor enables appropriate control strategies to be developed. In this study hospital based risk factors were not found to be significant. This is in contrast to a study in Ethiopia where history of hospitalization, tooth extraction, and blood transfusion were identified as major risk factors HCV infection [27].

The current study showed that HCV prevalence was highest in widows/widower and also in married individuals. This high prevalence may imply that transmission via sex is important in Rwanda. In order to break the cycle of HCV transmission, it is highly recommended that, screening among sexually active individuals be performed.

A significant observation made from this study is that $\mathrm{HCV}$ prevalence was highest among persons residing in Southern Rwanda followed by Western Rwanda. The high prevalence of infection in this part of Rwanda may be due to migration of persons at the border with Burundi where prevalence is highest in East Africa [12]. It is therefore recommended that more screening for persons living in Southern Rwanda and at various ports of entry be done.

In the present study, alanine aminotransferase (ALT) and aspartate transaminase (AST) values were not measured. Even though their values may not play a role in diagnosis of $\mathrm{HCV}$, they may be important in disease management $[35,36]$. They were however not tested due to the limitation of the study design. Liver biopsy was also not performed in this study due to obvious reasons such as cost, risk of complications, and need for additional health care resources [37]. The study was also unable to explore the issues relating to prevalence of HIV and HBV coinfections with $\mathrm{HCV}$ as these two infections have been shown to impact negatively the clinical course of chronic HCV infection [38-40]. With the high prevalence (9.6\%) of active HCV infection reported, a study the HIV and HBV coinfections with HCV would be of high priority.

\section{Conclusion}

The current study shows a high prevalence of HCV infection in Rwanda. Infection was more likely to occur in older persons than younger ones. Unsafe injections by traditional practitioners were of significant exposure risk of contracting $\mathrm{HCV}$ infection. The results further indicate that a person's place of birth and residence could determine their HCV status. Although, hematological abnormalities observed in this study were widespread among infected participants. This study indicates the need for a larger study to ascertain extent of HCV infections in Rwanda.

\section{Competing Interests}

The authors declare that they have no competing interests.

\section{Acknowledgments}

The authors wish to thank Dr. Ben Karenzi and Dr. Emmanuel Indahiro for their swift responses in making this study a success, the laboratory staff of the RMH for their technical supports, and Mr. E. M. Taylor for his assistance. This research was supported by the Pan African University of the African Union Commission for Science and Technology. Part funding was also received from the Japan International Corporation Agency (JICA) through AFRICA-ai-JAPAN PROJECT. 


\section{References}

[1] WHO, WHO-Hepatitis C, World Health Organization, Geneva, Switzerland, 2015.

[2] C. S. Graham and T. Swan, "A path to eradication of hepatitis C in low- and middle-income countries," Antiviral Research, vol. 119, pp. 89-96, 2015.

[3] R. Lozano, M. Naghavi, K. Foreman et al., "Global and regional mortality from 235 causes of death for 20 age groups in 1990 and 2010: a systematic analysis for the Global Burden of Disease Study 2010," The Lancet, vol. 380, no. 9859, pp. 2095-2128, 2012.

[4] J. T. Blackard, M. T. Shata, N. J. Shire, and K. E. Sherman, "Acute hepatitis C virus infection: a chronic problem," Hepatology, vol. 47, no. 1, pp. 321-331, 2008.

[5] R. T. Chung, "Acute hepatitis C virus infection," Clinical Infectious Diseases, vol. 41, no. 1, pp. S14-S17, 2005.

[6] B. Hajarizadeh, J. Grebely, and G. J. Dore, "Epidemiology and natural history of HCV infection," Nature Reviews Gastroenterology and Hepatology, vol. 10, no. 9, pp. 553-562, 2013.

[7] F. Kateera, T. D. Walker, L. Mutesa et al., "Hepatitis B and C seroprevalence among health care workers in a tertiary hospital in Rwanda," Transactions of the Royal Society of Tropical Medicine and Hygiene, vol. 109, no. 3, pp. 203-208, 2015.

[8] S. Nsanzimana, C. M. Kirk, J. P. Uwizihiwe, and H. C. Bucher, "Increasing access to hepatitis $\mathrm{C}$ treatment in Rwanda: the promise of Rwanda's existing HIV infrastructure," Journal of Infectious Diseases \& Therapy, vol. 3, no. 5, article 245, 2015.

[9] M. F. Pirillo, L. Bassani, E. A. P. Germinario et al., "Seroprevalence of hepatitis B and C viruses among HIV-infected pregnant women in Uganda and Rwanda," Journal of Medical Virology, vol. 79, no. 12, pp. 1797-1801, 2007.

[10] J. Rusine, P. Ondoa, B. Asiimwe-Kateera et al., "High seroprevalence of $\mathrm{HBV}$ and $\mathrm{HCV}$ infection in HIV-infected adults in Kigali, Rwanda," PLoS ONE, vol. 8, no. 5, Article ID e63303, 2013.

[11] D. Lavanchy, "Evolving epidemiology of hepatitis C virus," Clinical Microbiology and Infection, vol. 17, no. 2, pp. 107-115, 2011.

[12] M. J. Karoney and A. M. Siika, "Hepatitis C virus (HCV) infection in Africa: a review," The Pan African Medical Journal, vol. 14, no. 44, 2013.

[13] F. M. Averhoff, N. Glass, and D. Holtzman, "Global burden of hepatitis C: considerations for healthcare providers in the United States," Clinical Infectious Diseases, vol. 55, supplement 1, pp. S10-S15, 2012.

[14] I. W. Apata, F. Averhoff, J. Pitman et al., "Progress toward prevention of transfusion-transmitted hepatitis $\mathrm{B}$ and hepatitis C infection-Sub-Saharan Africa, 2000-2011," Morbidity and Mortality Weekly Report, vol. 63, no. 29, pp. 613-619, 2014.

[15] J. C. Eze, N. S. Ibeziako, A. N. Ikefuna, I. C. Nwokoye, N. D. Uleanya, and G. C. Ilechukwu, "Prevalence and risk factors for hepatitis $\mathrm{c}$ and human immunodeficiency virus coinfection among children in Enugu Nigeria," African Journal of Infectious Diseases, vol. 8, no. 1, pp. 5-8, 2014.

[16] C. E. Ramarokoto, F. Rakotomanana, M. Ratsitorahina et al., "Seroprevalence of hepatitis $\mathrm{C}$ and associated risk factors in urban areas of Antananarivo, Madagascar," BMC Infectious Diseases, vol. 8, article 25, 2008.

[17] L. Kish, "Survey sampling," Systematic Biology, vol. 46, no. 4, p. 643, 1965.

[18] Cypress Diagnosis, Anti-HCV Dipstick Product Information, Langdorp.
[19] Sysmex Corporation, Sysmex Automated Hematology Analyzer: XS series, 2006.

[20] S. G. Shelat, D. Chacosky, and S. Shibutani, "Differences in erythrocyte sedimentation rates using the Westergren method and a centrifugation method," American Journal of Clinical Pathology, vol. 130, no. 1, pp. 127-130, 2008.

[21] CAP/CTM HCV v2.0, “COBAS ${ }^{\circledR}$ AmpliPrep/COBAS ${ }^{\circledR}$ TaqMan ${ }^{\circledR}$ HCV Test”.

[22] IBM Corp. Released, IBM SPSS Statistics for Windows, Version 20.0, 2011.

[23] J. D. Stanaway, A. D. Flaxman, M. Naghavi et al., "The global burden of viral hepatitis from 1990 to 2013: findings from the Global Burden of Disease Study 2013," The Lancet, vol. 388, no. 10049, pp. 1081-1088, 2016.

[24] M. Lemoine, S. Eholié, and K. Lacombe, "Reducing the neglected burden of viral hepatitis in Africa: strategies for a global approach," Journal of Hepatology, vol. 62, no. 2, pp. 469476, 2015.

[25] J. P. Messina, I. Humphreys, A. Flaxman et al., "Global distribution and prevalence of hepatitis C virus genotypes," Hepatology, vol. 61, no. 1, pp. 77-87, 2015.

[26] L. Ikeako, H. Ezegwui, L. Ajah, C. Dim, and T. Okeke, "Seroprevalence of human immunodeficiency virus, hepatitis $B$, hepatitis $\mathrm{C}$, syphilis, and co-infections among antenatal women in a tertiary institution in South East, Nigeria," Annals of Medical and Health Sciences Research, vol. 4, no. 6, pp. 954-958, 2014.

[27] A. H. Atsbaha, T. A. Dejen, R. Belodu, K. Getachew, M. Saravanan, and A. G. Wasihun, "Sero-prevalence and associated risk factors for hepatitis $\mathrm{C}$ virus infection among voluntary counseling testing and anti retroviral treatment clinic attendants in Adwa hospital, northern Ethiopia," BMC Research Notes, vol. 9, no. 1, article 121, 2016.

[28] E. Seremba, P. Ocama, C. K. Opio et al., "Poor performance of hepatitis C antibody tests in hospital patients in Uganda," Journal of Medical Virology, vol. 82, no. 8, pp. 1371-1378, 2010.

[29] World Health Organization, Guidelines for the Screening, Care and Treatment of Persons with Hepatitis CInfection, Guidelines, 2014.

[30] H.-Y. Rao, D.-G. Sun, D. Jiang et al., "IL28B genetic variants and gender are associated with spontaneous clearance of hepatitis C virus infection," Journal of Viral Hepatitis, vol. 19, no. 3, pp. 173181, 2012.

[31] J. M. Micallef, J. M. Kaldor, and G. J. Dore, "Spontaneous viral clearance following acute hepatitis $\mathrm{C}$ infection: a systematic review of longitudinal studies," Journal of Viral Hepatitis, vol. 13, no. 1, pp. 34-41, 2006.

[32] I. Bakr, C. Rekacewicz, M. El Hosseiny et al., "Higher clearance of hepatitis $\mathrm{C}$ virus infection in females compared with males," Gut, vol. 55, no. 8, pp. 1183-1187, 2006.

[33] J. I. O’Reilly, P. Ocama, C. K. Opio et al., "Risk factors and seroprevalence of hepatitis $\mathrm{C}$ among patients hospitalized at Mulago Hospital, Uganda," Journal of Tropical Medicine, vol. 2011, Article ID 598341, 6 pages, 2011.

[34] F. Abdel-Aziz, M. Habib, M. K. Mohamed et al., "Hepatitis $\mathrm{C}$ virus (HCV) infection in a community in the Nile Delta: population description and HCV prevalence," Hepatology, vol. 32, no. 1, pp. 111-115, 2000.

[35] B. Roshan and G. Guzman, "Histological and clinical characteristics of patients with chronic hepatitis $\mathrm{C}$ and persistently normal alanine aminotransferase levels," Hepatitis Research and Treatment, vol. 2014, Article ID 760943, 6 pages, 2014. 
[36] M. Abdel-Rahman, Y. Saad, M. El-Raziky et al., "Hepatitis C genotype 4 with normal transaminases: correlation with fibrosis and response to treatment, a cohort Egyptian study of 4277 patients," Clinics and Research in Hepatology and Gastroenterology, vol. 37, no. 5, pp. 479-484, 2013.

[37] R. S. O'Shea, N. Alkhouri, and W. Caarey, "Hepatitis C," http:// www.clevelandclinicmeded.com/medicalpubs/diseasemanagement/hepatology/hepatitis-C/.

[38] Z. Liu and J. Hou, "Hepatitis B virus (HBV) and hepatitis C virus (HCV) dual infection," International Journal of Medical Sciences, vol. 3, no. 2, pp. 57-62, 2006.

[39] V. Soriano, E. Vispo, P. Labarga, J. Medrano, and P. Barreiro, "Viral hepatitis and HIV co-infection," Antiviral Research, vol. 85, no. 1, pp. 303-315, 2010.

[40] Y.-H. Zhou, Z.-H. Yao, F.-L. Liu et al., "High prevalence of HIV, $\mathrm{HCV}, \mathrm{HBV}$ and co-infection and associated risk factors among injecting drug users in Yunnan Province, China," PLoS ONE, vol. 7, no. 8, Article ID e42937, 2012. 


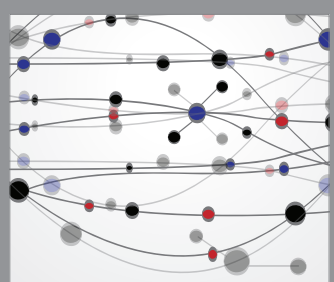

The Scientific World Journal
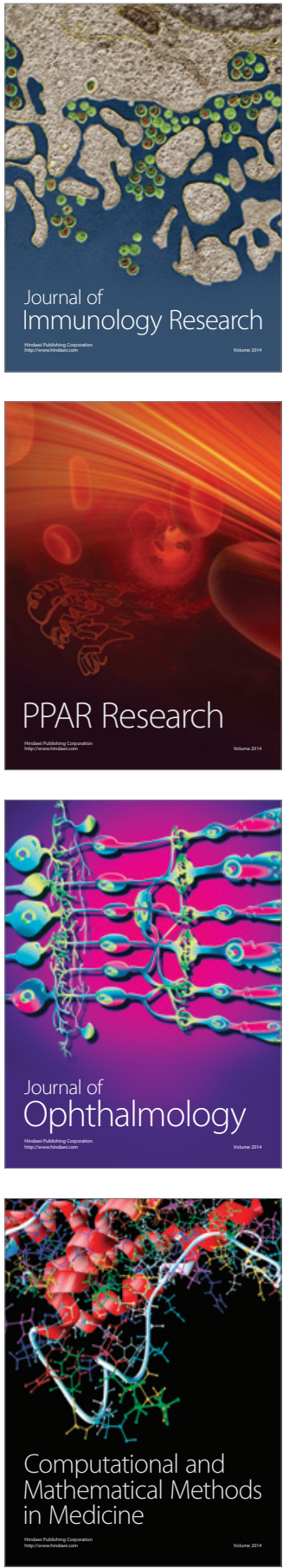

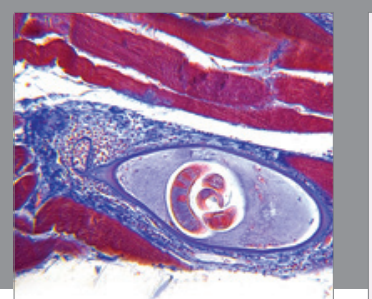

Gastroenterology Research and Practice
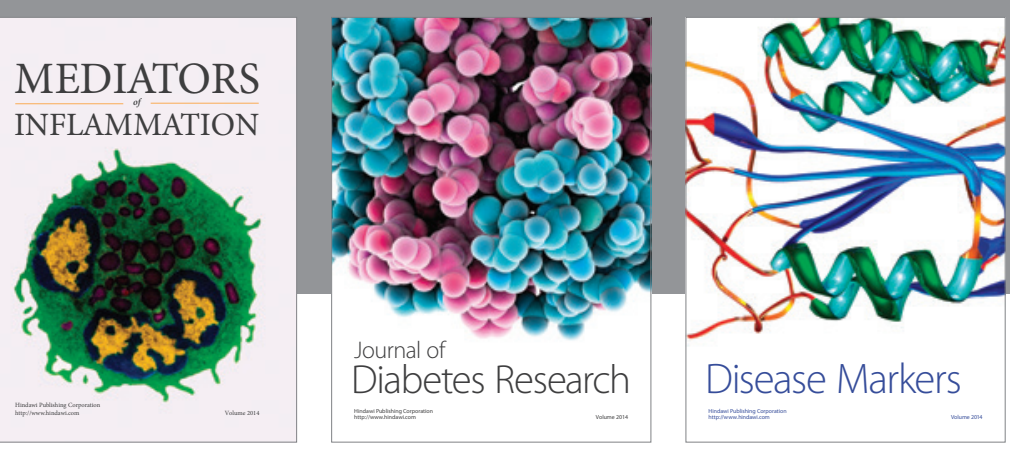

Disease Markers

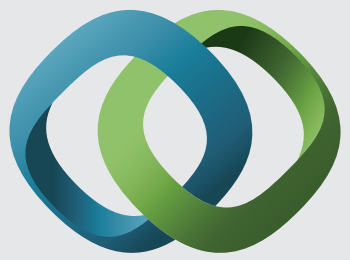

\section{Hindawi}

Submit your manuscripts at

https://www.hindawi.com
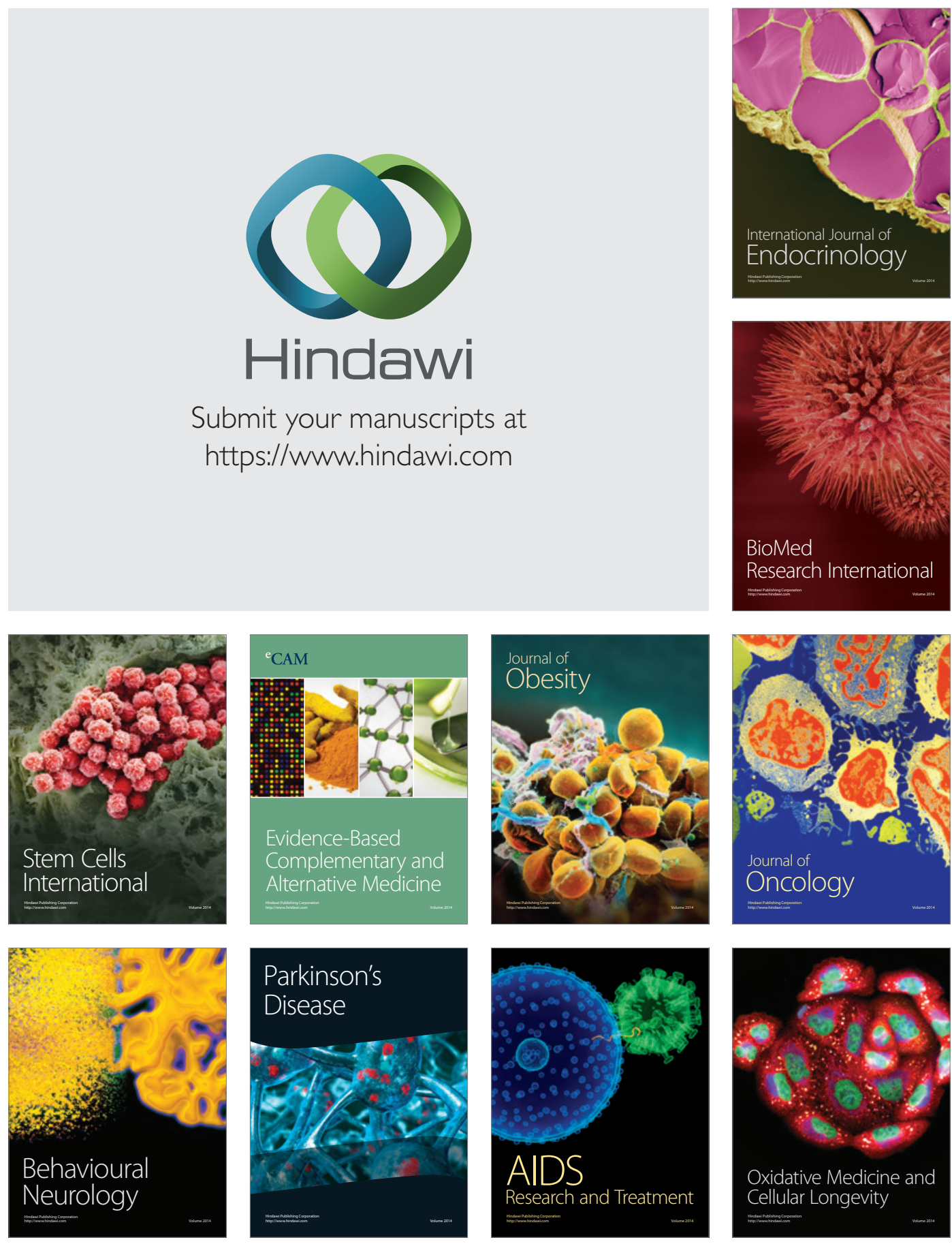